\title{
Social, cultural, economic and mangrove resources Gampong Lapeng, Pulo Breuh, Aceh Besar
}

\author{
Khansa Iklila Hanifa, Najmi Rinjani Ferdian, Suha Rakata Ferdian, Agha Alamulhuda Husein, Thariq Abdurrahman, \\ Maria Ulfa $^{*}$
}

Perkasa Alam School, Banda Aceh 23234, Indonesia

\begin{abstract}
Socio-cultural and economic a society will be able to help provide information related to the condition of the community. Mangroves are plants that are the result of cultivation activities or taken from nature. This research aims to find out the social, cultural, economic and also mangrove conditions that remain in Gampong Lapeng. In addition, to get to know the preservation of culture and customs in Gampong Lapeng. The benefit of this activity is to provide information and science. This research uses descriptive qualitative methods with a study subject of 5 people. The plot used in this investigation is as much as 1 plot covering an area of 50x50 meters. The results showed that the social conditions of lapeng community are open and friendly in accepting guests who come to visit. A very thick culture in the village of Lapeng is the advice not to go to sea on Fridays. The economic conditions of the villagers depend on the weather and the sea season. In the east wind season the income generated at sea will decrease nominally because fishermen can find fish easily. The types of mangroves in Gampong Lapeng are Rhizophora and Avicennia.
\end{abstract}

\section{Introduction}

Mangrove forests are plants that grow between the tidal lines, so mangrove forests are also called tidal forests. Mangroves are very rare ecosystems, because they are very small, which is about $2 \%$ of the earth's surface. Literally, this mangrove forest weld is only about $3 \%$ of almost all forest areas and $25 \%$ of all mangrove forests in the world [1].

Mangrove forest ecosystems in Indonesia are currently in critical condition, this is due to damage of almost $68 \%$ or about 5.9 million hectares of mangrove forest. This condition is very concerning, because of the magnitude of mangrove functions and benefits for marine life. To improve this condition, there needs to be a change in the landscape and the way of looking at the community related to mangroves and how to take other natural resources around mangroves. Because mangroves ecosystems have a function to maintain land from the grinding of waves and other marine biota living places [2].

Mangrove Forest area in addition to serving to keep the land from coastal abrasion, also as a provider of foodstuffs for human life. Where humans consume fish, shrimp, crabs and crabs and energy sources for life on the beach such as plankton, nectar and algae [3]. The physical function of mangrove forests is to keep the coastline stable, protect beaches and river cliffs from erosion and abrasion and resist or absorb very strong angina during the wind season. The chemical function of the mangrove ecosystem is the place where the recycling process that eliminates oxygen, as the absorption of carbon dioxide, as a processor of waste materials from pollution from industry and large ships in the ocean [4 Arief, 2003].

Geographically, Pulo Aceh District borders the Strait of Malacca and The Strait of Bengal to the North, Peukan Bada District in the South, Sabang Waters to the East, and the Indian Ocean to the West. The area of Pulo Aceh Subdistrict reaches $240.75 \mathrm{Km} 2$ and consists of 3 Kemukiman, namely Nasi Island, South Breueh Island and North Breueh Island Resettled. Nasi Island consists of 5 villages, namely Alue Reuyeueng, Deudap, Lamteng, Pasi Janeng and Rabo. The resettled of South Breueh Island consists of 8 villages, namely Lampuyang, Lhoh, Paloh, Blang Situngkoh, Ulee Paya, Gugop, Seurapong and Teunom. The resettledness of North Breueh Island consists of 4 villages, namely Alue Raya, Lapeng, Meulingge and Rinon. Lapeng village located in the village of Breuh Island is one of the very remote villages, and still belongs to the remote indigenous community (KAT) of Aceh. Lapeng village is one of the village in Pulo Aceh District, Aceh Besar Regency, Aceh, Indonesia. Which the population in Lapeng village is 174 people from 46 Kartu Keluarga (Family Certificate).

Geographically the location of Lapeng village is very remote so access to the village is very difficult, as well as vehicles to the village. There are only one or two vehicles such as pick up cars that residents can use as a daily transportation. So, this greatly affects the economy of Lapeng residents. Other facilities such as health facilities and educational facilities are also very limited, making it difficult for residents. So, if the citizens want

\footnotetext{
* Corresponding author: bundaulfa1981@gmail.com
} 
to seek treatment must take a long way out of this Lapeng village. Likewise for educational facilities, there is only one elementary school and four teachers who will teach alternately. Very concerning and distressing conditions.

Based on the initial picture obtained by the Kids Survivor team, the research team together with field supervisors wanted to conduct further field studies related to the condition of mangrove natural resources in Lapeng village as well as the social conditions of the people, economy and culture of Lapeng village residents.

\section{Methodology}

\subsection{Place and Time of Research}

The research was carried out for 6 (six) days, from 27 march to 1 April 2021. The research location is in Lapeng village, Breuh Island Sub-District, Pulo Aceh, Aceh Besar District. Determining the location based on it is remote location, and also as a location for empowering remote location. Determining research locations based on their geographical location and conduct mangrove research as well as economic, social, and cultural research.

\subsubsection{Type of research}

The type of research we use is a type of qualitative research. According to [5], qualitative research is research used to investigate, discover, describe, and explain the qualities or privileges of social influences that cannot be explained, measured or described through quantitative approaches. Cauldron research is a type of research whose findings are not obtained through statistical procedures or other forms of calculation and seek to understand and estimate the meaning of an event of human interaction in certain situations according to the researcher's own perspective.

\subsubsection{Scope of Research}

The scope of research covered demographic, social, economic, cultural, and identification data on mangrove plants on the coast of Lapeng village.

\subsubsection{Data Collection Techniques}

Data collection techniques in the form of observations, interviews, and FGD (focus group discussion). The research team made observations by mingling directly with the village community to observe the social conditions of the community. Interviews were conducted face-to-face with village heads and local residents and informants who were mentors in the research. FGD was conducted with several villagers in the form of discussions related to the focus of research.

\subsection{Data Analysis}

The data obtained in the field is analysed with qualitative methods which are then presented using descriptive methods to describe mangrove's economic, social, cultural, and natural resources conditions.

\section{Results}

\subsection{Overview and Social, Economic, Cultural Conditions of Research Locations}

The research location of the Kids Survivor team is in 1 (one) village, namely Lapeng village, Pulo Aceh subdistrict, Aceh Besar.

\subsection{Geographical Location}

Lapeng Village is one of the village located in Pulo Aceh subdistrict, Aceh Besar Regency. From bps Pulo Aceh data, Aceh Besar regency in 2020 said that Lapeng village is located on the coast and has a village area of $06.77 \mathrm{Km} 2$. This village includes the mukim of north Breuh island which oversees 4 (four) village, namely Alue Raya village, Rainon village, Meulingge village, and Lapeng village. In this village, there is 1 keuchik (head of a village), 1 Sekretaris Desa (secretary of a village) 2 Kepala Dusun (head of a hamlet), and one Kepala Urusan (head of affairs). This village is very remote and located far from the capital of the district. So that this village can be called an inland area.

As a deepening area, Lapeng village has natural wealth in the form of plants. One of the potential plants is mangroves. This plant is also often called Bak Bangka in the area. Mangroves are one of the rare ecosystems that grow between tidal lines. So it needs to be a good time in preserving it. In addition to mangroves, Lapeng villages do not have many specific natural resources, this is because the villagers prefer to go to sea rather than farming. This is because the area of Lapeng village is still far away.

The village also includes a remote indigenous community empowerment location (KAT). KAT itself is a group of people who live in remote areas, where the area is in a condition of not enough both clothing and food. The area is also vulnerable to social, economic, and isolated from the outside world.

\subsection{Mileage and Accessibility}

The distance from the Provincial Capital (Banda Aceh) to the District Capital (Lampuyang) is reached within 1.5 - 2 hours using a fishing boat as far as the road. The cost used is also not small, because visitors have to rent a special vehicle to get to the village. This is due to the absence of public transportation to go there. Furthermore, access from the sub-district to Lapeng village can be reached by four-wheeled or two-wheeled vehicles for 90 minutes as far as approximately $5 \mathrm{~km}$. This is due to the condition of the road terrain traversed across mountains and unpaved rock roads. 


\subsection{Population}

According to Badan Pusat Statistik (BPS) (Central Bureau of Statistics) data in 2020, totaled 154 people in 56 Kartu Keluarga/KK (family certificate). $100 \%$ of the villagers are Muslim. In the Lapeng region, not each KK has each house. There are houses that have 2 or more $\mathrm{KK}$ in them. The population density of this village has 23 inhabitants. The condition of the village with the number of residents who are not crowded, shows the characteristics of Lapeng villagers who have a very friendly nature. This can be seen from the ethics when migrants arrive in their villages. With friendly and welcome residents warmly welcome the immigrants, whether it is guests or students and children.

\subsection{Livelihoods and Economic Activities}

The majority of Lapeng residents are generally gardening, trading, and sea. Plantations that are cultivated include, yam, cucumber, nutmeg, chili, and cassava. For fishermen, one of the species that are often sought is octopus which will later be traded. They also produce some fish that are sold to buy fellow villagers.

The commonly marketed crop commodity is nutmeg. Because the distance and travel between the village and the sub-district capital is inadequate, residents usually market their plantations and catches by selling with fellow residents. As for basic needs such as rice, residents do buy and sell with other villagers or by being visited by residents from sub-district villages. This is due to the lack of farming. This is due to the presence of several pests in the form of monkeys that disturb plants. Villagers also take advantage of their forests. Forest products commodities such as clean water sources, and wood sources for local purposes such as house construction and others. Forests in Lapeng village also act as NTFB (Non-Timber Forest Products).

\subsection{Public Facilities and Facilities}

In general, social facilities and public facilities are very minimal. Lapeng village has only one elementary school with a total of 6 classes and 2 teachers. Because of its location in the interior, the school provides a simple home to be occupied by teachers. As a deepening area, some houses in Lapeng village already have public bathing, washing, and toilet facilities. Each house has at least 1 bathroom that can be used for bathing and purifying.

For matters of worship, Lapeng village already has a mushalla that can be used for prayer and other worship. Residents also have rooms such as halls to conduct meetings, citizen associations or something like that. The hall is made of wood, which residents and children use to study. Lapeng village also has a reading garden, which children can use to read books. Many donations they get from some immigrants in the form of reading books and textbooks that will later be facilitated in the reading park.

Table 1. Facilities in Lapeng village

\begin{tabular}{|c|c|c|c|c|c|c|c|c|}
\hline \multirow[t]{2}{*}{ No. } & \multirow[t]{2}{*}{ Type of Facilities } & \multirow[t]{2}{*}{ Total } & \multicolumn{3}{|c|}{ Condition } & \multicolumn{3}{|c|}{ Usage } \\
\hline & & & B & $\mathrm{C}$ & $\mathrm{R}$ & $\mathrm{S}$ & $\mathrm{J}$ & TP \\
\hline 1 & $\begin{array}{l}\text { Educational Facilities } \\
\text { - Elementary school } \\
\text { - Study Hall } \\
\text { - Reading Garden }\end{array}$ & $\begin{array}{l}1 \\
1 \\
1\end{array}$ & $\begin{array}{l}\sqrt{ } \\
\sqrt{ } \\
\sqrt{ }\end{array}$ & & & $\begin{array}{l}\sqrt{ } \\
\sqrt{ } \\
\sqrt{ }\end{array}$ & & \\
\hline 2 & $\begin{array}{l}\text { Religious Facilities } \\
\text { - Mushalla } \\
\text { - Study Hall }\end{array}$ & $\begin{array}{l}1 \\
1\end{array}$ & $\begin{array}{l}\sqrt{ } \\
\sqrt{ }\end{array}$ & & & $\begin{array}{l}\sqrt{ } \\
\sqrt{ }\end{array}$ & & \\
\hline 3 & $\begin{array}{l}\text { Public Service Facilities } \\
\text { - Bridge }\end{array}$ & 1 & $\sqrt{ }$ & & & $\sqrt{ }$ & & \\
\hline 4 & Cemetery/Graveyard & 1 & & & $\sqrt{ }$ & & $\sqrt{ }$ & \\
\hline 5 & Transportation & & & $\sqrt{ }$ & & $\sqrt{ }$ & & \\
\hline
\end{tabular}

Description: Condition: B: good; C: enough; R: broken. Usage : S: frequent; J: rare; TP: never.

\subsection{Social and Cultural Interaction}

\subsubsection{Socio-Cultural Life}

This village has a unique culture, among them, local residents should not work on the day that the villagers do their studies. Also, in this village there is a middleaged woman whose cuisine is very enjoyed by the locals. Many people buy or get some food from her. No wonder if some similar foods found in several different homes later (Table 2).

\subsection{Language}

The majority of villagers use Acehnese in their daily lives. Some of them can understand Indonesian but only a small number. This is because of the length of time they live in the village and almost all residents use Acehnese. Even migrants have to adapt to use the language of the region.

\subsection{Mangrove}

The mangrove observation site area is just behind SDN (Public Alimentary School) Lapeng. Mangrove areas are also located on the coast, where the area has become a waste area.

\subsubsection{Type and number}

Based on the results of mangrove analysis in the plot of 50x50 meters found 12 amounts of vegetation and consisted of 2 types. The types of mangroves located in the mangrove forests of Lapeng Village in detail will be described in Table 3.

It is known that at least the number of mangroves in the plot of 50x50 is caused by the tsunami in 2004 ago. Therefore, most of the mangroves disappeared and only a few species remained in small numbers. 
Table 2. Social, economic and cultural data in Lapeng village

\begin{tabular}{|c|c|c|c|c|c|c|}
\hline MENU & Forest & Garden & Settlement & River & Coast & Sea \\
\hline \multirow{6}{*}{$\begin{array}{l}\text { Social \& } \\
\text { Economic }\end{array}$} & \multirow{6}{*}{ hunter } & Garden Farmer & - Grocery & \multirow{6}{*}{ - } & \multirow{6}{*}{ Stall } & Fisherman \\
\hline & & Cattle & - Teacher & & & Fish Shelter \\
\hline & & Rancher & - Hall & & & \\
\hline & & & - Mushalla & & & \\
\hline & & & - Hall & & & \\
\hline & & & - Park Read & & & \\
\hline \multirow[t]{2}{*}{ Culture } & \multirow[t]{2}{*}{$\begin{array}{l}\text { Prohibition of } \\
\text { cutting down } \\
\text { trees around } \\
\text { settlements and } \\
\text { water sources }\end{array}$} & \multirow{2}{*}{$\begin{array}{l}\text { Gardening ban } \\
\text { from Thursday } \\
\text { afternoon to } \\
\text { Friday } \\
\text { afternoon }\end{array}$} & \multirow[t]{2}{*}{$\begin{array}{l}\text { Not going to } \\
\text { sea and farming } \\
\text { every Monday }\end{array}$} & \multirow[t]{2}{*}{$\begin{array}{l}\text { Prohibition of } \\
\text { cutting down } \\
\text { trees in the } \\
\text { river }\end{array}$} & Abeh & \multirow{2}{*}{$\begin{array}{l}\text { Gardening ban } \\
\text { from Thursday } \\
\text { afternoon to } \\
\text { Friday } \\
\text { afternoon }\end{array}$} \\
\hline & & & & & Wednesday & \\
\hline
\end{tabular}

Table 3. Types and number of mangroves.

\begin{tabular}{|c|c|c|c|c|c|c|}
\hline No & Leaf & Flower & Fruit & Rot & Type & Sum \\
\hline 1 & Taper & $\begin{array}{c}\text { Armpit } \\
\text { leaves }\end{array}$ & Cylinder & Support & Rhizophora & 5 \\
\hline 2 & Oval & Edge & Round & Breath & Avicennia & 7 \\
\hline \multicolumn{3}{|c|}{ Total } & \multicolumn{3}{|c|}{12} \\
\hline
\end{tabular}

\subsubsection{Abundance}

[5] states that relative abundance is the proportion presented by each species of an entire individual in a community. Mangrove abundance results will be detailed in Table 4.

Based on the results of the calculation of abundance in the mangrove ecosystem of Lapeng village, the overall mangrove abundance reached 0.0048 .

Table 4. The abundance of mangroves

\begin{tabular}{|c|c|c|c|c|}
\hline No & $\begin{array}{c}\text { Plot Area } \\
\text { (unit) }\end{array}$ & $\begin{array}{c}\text { Number of } \\
\text { species }\end{array}$ & Type & Result \\
\hline 1 & $50 \times 50$ & 5 & Rhizophora & 0,002 \\
\hline 2 & $50 \times 50$ & 7 & Avicennia & 0,0028 \\
\hline \multicolumn{3}{|c|}{ Total } & \multicolumn{2}{c|}{0,0048} \\
\hline
\end{tabular}

\section{Discussion}

The bottom of the waters of the mangrove area of Lapeng village is dominated by sand and a little clay. Mangrove area itself is used as a playground for village children. This is because the mangrove area located near the coast is not maintained. Even only left behind a few remaining species after the tsunami hit Aceh.

In this region, the team took data by identifying leaves, flowers, roots, and fruit from mangrove stems. This makes it easier to know the type of species being identified. The team must also know the function of mangroves in addition to their speciess. [6] mentions several functions of mangrove forests. including keeping the coastline stable, protecting the coast from erosion (abrasion), as well as dampening waves and storms, as mud retainers, flood control, treating waste materials, maintaining water quality, $\mathrm{CO} 2$ absorbers and $\mathrm{O} 2$ producers and reducing the risk to tsunami hazards. Ecologically, mangroves also function very important in playing a role as a food chain in a water, where it can ride the lives of various types of fish, shrimp and mollusks.

If treated further, mangroves can also be beneficial for social and economic. From the [6] mentioned that mangroves are useful as a search eye, including the production of various forest products, such as wood, charcoal, medicine and food. Mangroves are also useful as a source of building materials and crafts, natural attractions, educational and research objects, mooring areas, salt making grounds and plantation areas.

In mangrove identification activities, the team also taught village children about mangrove data retrieval. The reason for doing this, goes back to the title of the team activity, namely give and take. Which we take and give knowledge to. Not enough to get there, the team will also make a presentation later in front of the villagers. Not only identifying mangrove data, the team also conducted personal projects, including dumpling, cooking projects, making Thai tea, handicrafts in the form of bracelets and necklaces, teaching football techniques, and storytelling the story of the prophet. This is expected to be useful and add insight to the village children. The same goes for people who not only let us learn, but also teach. Starting from cultural, social and economic. Details per detail of the residents are ready to give us information about the village.

Around the mangrove area, there is a pier. From Wikipedia, it is said that the pier is where the ship is moored in the harbor. It is also the place where the loading and unloading activities and ups and downs of people or passengers or goods from and to the ship. The community also provides stalls on the pier. In addition, the community also buys and sells fish and other marine animals, such as octopuses. Not only in the dock, local residents also do buys and sells fellow in the village. Like nutmeg producers, which can later be sold to interested citizens. Also, there are people who work as grocery managers. Residents also buy daily necessities at the grocery such as oil, sugar, eggs, milk and so on. 
Head of a village's mother also opened a meatball business in her house, which made many visitors often visit their house.

In addition to business, residents also work as hunters. It's not public works even $2 / 10$ of working people do. Similarly, planters, who often stop working because their gardens are damaged by pests or farm animals, such as monkeys, cows, and goats. For the teaching part, residents also act as teachers in the village. Residents held studies for the village children, with one of their residents as a guide. Studies are held every afternoon between 5.00-6.00 PM. This study is not compulsory for all children to follow, but almost all children join. Unlike the school, which residents provide a teacher's home in the school yard. With that the teacher does not need to go back and forth from home to school. The study hall is also used as a facility for guests or immigrants to conduct their programs.

Lapeng village has a reading house that children use as a library and playground. Sometimes also the village is visited by immigrants or guests from outside who teach the village children many things, including reading. As did the Kids Survivor team, which taught them the story of the Prophet of choice by storytelling. To help the village, visitors can also donate some reading books that can later be read by village children.

Socio-cultural and economic a society will be able to help provide information related to the condition of the community. This research aims to find out the social, cultural, economic and also mangrove conditions that remain in Lapeng village. Mangroves are plants that are the result of cultivation activities or taken from nature. The purpose of this activity is to get to know the preservation of culture and customs in Lapeng village. In addition, to identify the types of mangroves in Lapeng village to find out the source of income of Lapeng village residents. The benefit of this activity is to provide information and science. This research uses descriptive qualitative methods with a study subject of 5 people. The plot used in this investigation is as much as 1 plot covering an area of 50x50 meters. The results showed that the social conditions of Lapeng people openly and kindly accept guests who come to add knowledge. The very thick culture in the village of Lapeng village is brotherly bond or a meal together that was done thursday night to strengthen the bonds of brotherhood. The economic conditions of the villagers depend on the weather and the sea season. In the east wind season the income generated at sea will decrease nominally because fishermen can find fish easily.

\section{Conclusion}

Based on the results of the analysis it be concluded that the social condition of Lapeng community has strong social ties, unpretentious with immigrants and accepts immigrants and guests in a friendly manner. Lapeng residents strongly hold fast to customs and uphold religion. The economic level of Lapeng village community has a sufficient level of economy to meet the needs of daily living, the recovery of can be from sea, farming and gardening and trading.
While the natural resources of mangrove forests have not been used as the main source of livelihood for the residents of Lapeng village. However, the residents of Lapeng village continue to be sustainable mangrove forests because children of Lapeng use mangrove forests as their playground.

Acknowledgments. Thank you to all those who have supported service activities in Lapeng village. WCS Institute, University of Muhammadiyah Aceh, HAkA which has provided both moral and material support in the implementation of this activity. The results of this research can provide information related to the condition of Lapeng village for further researchers by taking different topics or deepening the social and cultural data of Lapeng village.

\section{References}

1. C. Saparinto. Utilization of Mangrove Ecosystems. Semarang: Publisher of Dahara Prize (2007)

2. A. W. Setyawan. Biodiversity, 7, 2 (2006)

3. M. Bismark, E. Subiandono, N. M. Heriyanto Ed. Nat. Conser., 5, 7 (2008)

4. Arief. Hutan Mangrove Fungsi dan Manfaatnya. Yogyakarta: Knisius (2003)

5. N. A. Campbell, J.B. Reece. Biology, Eighth Edition Volume 3 (Translation: Damaring Tyas Wulandari). Jakarta: Erlangga. (2010)

6. Ujung Kulon Conservation Society. (2010). Manfaat Penanaman Mangrove. http://Ucsindonesia.Org/Index.Php?Option=Com Content\&View=Article\&Id=74:ManfaatPenanama nMangrove $\&$ Catid $=1:$ Latest $\&$ Itemid $=117$ 